肺癌または血管肉腫との鑑別に難渋した，胸部大動脈解離の症例

岩井俊, 山形 愛可, 関村 敦
本野 望, 薄田 勝男, 浦本 秀隆

\begin{abstract}
要 旨
症例は 50 歳, 女性. 造影剤アレルギーのため入院歴があった. 左肺上葉に大動脈弓部遠位部に接する結節性病変を認め, PET-CT では同部位にFDG の高度集積を認めた，肺癌または血管肉腫を疑ったが，胸部 MRIで胸部大動脈解離を認めた。 ステントグラフト内拌術 $(\mathrm{TEVAR})$ を施行し, 胸胿鏡下生検術を行う方針となった. 喀血, 腫瘤径の増大と肺内出血を認め TEVARによる緊急手術をし, 術後に気管支鏡検査を行ったが, 診断に至らなかった. しかし胸部 CT で腫瘤が縮小し, 大動 脈解離による炎症性腫瘤と診断された，本症例は造影剂による画像診断が不可能であり診断に難渋した，胸脉鏡下生検術に より診断する予定であったが，大動脈解離の合併があり出血のリスクが高く，困難な状況であった，悪性腫瘍と良性腫瘍と の鑑別方法として胸胿鏡下生検術が有用であるが，大動脈解離の併存により困難であった症例を経験したので文献的考察を 加えて報告する.
\end{abstract}

索引用語：肺癌, 血管肉腫, 胸部大動脈解離

lung cancer, hemangiosarcoma, thoracic aortic dissection

\section{はじめに}

大動脈に浸潤した肺癌や大動脈原発肉腫の予後は不良 である ${ }^{1,2)}$. 近年では大動脈浸潤の肺癌に対する手術も施 行されるようになっており, 肺癌診療ガイドライン 2018 年版に抒いても長期予後が期待でき, 外科切除の良い適 応としている3. しかし, いずれの疾患も造影 CT 等の画 像検查は診断に必要不可欠である。結果的には大動脈解 離による炎症性腫瘤ではあったが，今回我々は造影剤ア レルギーの既往のあるため造影 CT をすることが困難で あり, 肺癌または血管肉腫の鑑別に難渋した, 胸部大動 脈解離の症例を経験したので, 文献的考察を加えて考察 する.

\section{症例}

症 例: 50 歳 女性.

金沢医科大学呼吸器外科

原稿受付 2020 年 3 月 2 日

原稿採択 2020 年 5 月 21 日

本論文の要旨は第 60 回日本肺癌学会学術集会にて発表した.
主 訴：胸部異常陰影.

既往歴：気管支喘息, 骨粗鬆症.

現病歴：健診の胸部 X 線で左上肺野の胸部異常陰影 を指摘され，当院呼吸器内科を受診した，画像上，腫瘍 は大動脈に接するように存在し，縦隔にまで及んでいた ため，肺癌の大動脈浸潤を疑われた。気管支鏡検査で細 胞診が陰性で診断が確定しなかったため，胸腔鏡下肺生 検術目的で当科に紹介となった.

アレルギー：造影剤アレルギー $(24$ 歳時に顔面に蕁麻 疹が生じ, 入院歴があった)。

入院時現症 : 身長 $133 \mathrm{~cm}$, 体重 $31.8 \mathrm{~kg}$, 血圧 126/99 $\mathrm{mmHg}$, 脈拍 66/min, SpO2 98\% (room air).

血液検査所見：血算, 生化学に異常所見は認めなかっ た.また腫瘍マーカーは全て正常範囲内であった。

胸部 X 線（Fig. 1）：左上肺野に浸潤影を認めた。

胸部 CT (Fig. 2a, b) : 左肺上葉 $\mathrm{S} 1+2$ に $37 \mathrm{~mm}$ 大の 大動脈弓部遠位に接する結節影を認めた。

PET-CT（Fig. 2c）：同部位に高度集積（SUVmax： 6.05）を認めた。

胸部 MRI（Fig. 3a，b，c）：T1 強調画像では腫瘤部位 
の信号は大血管と同等であった. T2 強調画像では内部の 背側部は高信号, 底部は低信号で, 壁構造は肥厚してい た. 拡散強調画像では弓部遠位腫瘤状突出部や壁外軟部 信号, 肥厚した大動脈壁に高信号を認めた。

経 過：当科と呼吸器内科と心臟血管外科, 放射線科 とで conferenceを行った結果, 肺癌または血管肉腫, 胸 部大動脈解離による大動脈炎が疑われた. 治療方針とし て, 胸部動脈解離に対して胸部大動脈ステント術 (TEVAR) を施行し, その後に胸腔鏡下肺生検術を行う こととなった。 しかし, その 1 力月後に咳嗽後に夜間喀 血を来たし, 当院救急を受診した，胸部 CT (Fig. 4a，b) では胸部大動脈解離と腫瘤陰影の増大と右肺上葉に肺内

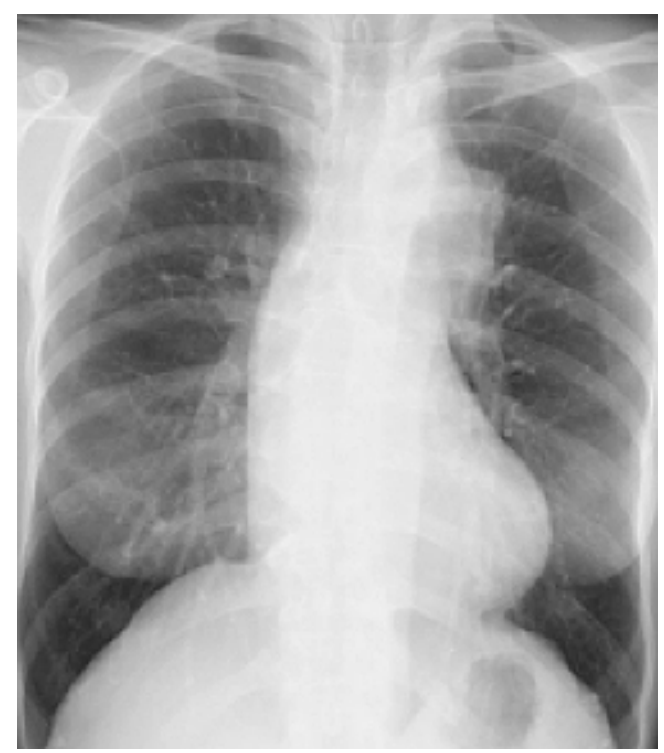

Fig. 1 A nodule shadow in the left lung was pointed out on a chest radiograph.
出血を認めた。当科と呼吸器内科, 心臓血管外科とで再 度 conference したが, 肺胞内出血による喀血との見解と なり, 呼吸器内科に入院となった。しかし, 今後大量喀 血のリスクが高いことも考慮され, 緊急でTEVAR (Fig. 5a)を施行することとなった. TEVAR 施行後も大動脈破 裂の危険性があったため, 胸腔鏡肺生検術は後日行うこ ととし，気管支鏡検查（Fig. 5b）のみを施行したが，細 胞診は再度陰性であった。

術後経過：TEVAR 施行後, 胸部 CT で経過観察され たところ, 徐々に陰影の縮小を認めた。術後 5 力月目の 胸部 CT（Fig. 6a，b）では腫瘤陰影は完全に消失してい た.

\section{考察}

本症例は胸部 CTより大動脈浸潤肺癌が疑われ，胸部 MRI にて血管肉腫または胸部大動脈解離による大動脈 炎が疑われた。しかし, 突然の喀血により胸部大動脈解 離による切迫破裂を疑われ, 緊急 TEVARを施行され た. 結果的にその後の画像検查で結節陰影は縮小し消失 を認めたため, 最終的に胸部大動脈解離による大動脈炎 と診断が確定した。

本症例において鑑別を難渋させた最大の要因は造影剂 アレルギーの既往があったことである.仁科ら ${ }^{4}$ は炎症性 の解離性大動脈瘤において造影 CT 所見は確定診断に意 義のあるものだと報告している。炎症性の解離性大動脈 瘤の造影 CT 所見では炎症により強い造影効果を伴う前 側壁を中心に肥厚した瘤壁（mantle core sign）や周囲臓 器を巻き込むように増殖した線維性肥厚が診断に重要な 所見である ${ }^{5)}$. 炎症性解離性大動脈瘤の文献はいくつか散
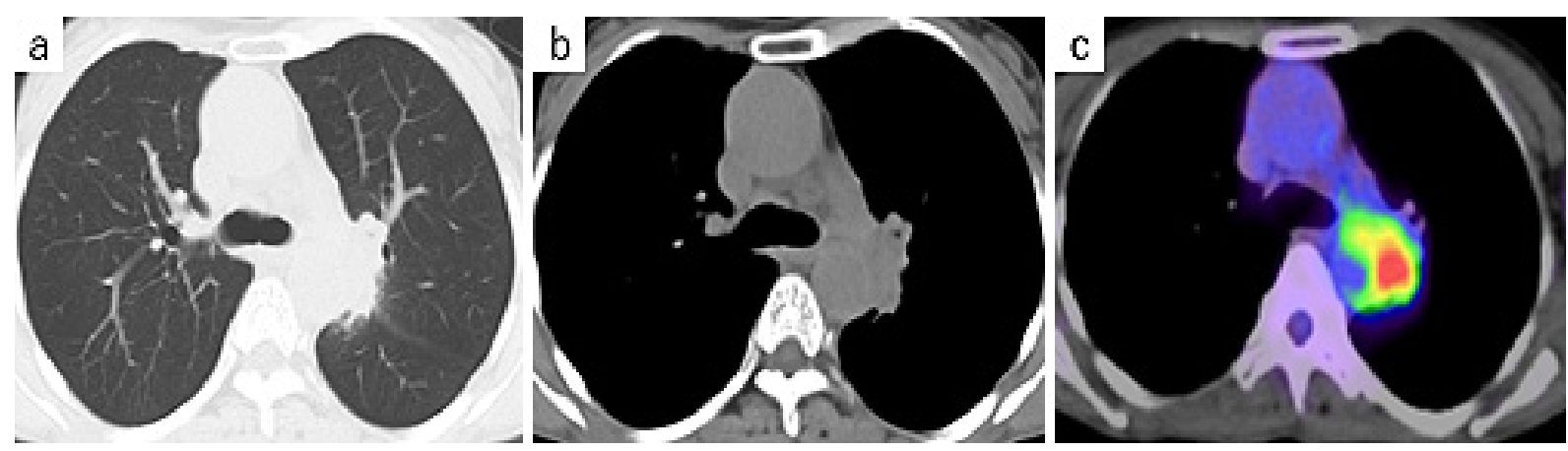

Fig. 2

(a) (b): Chest CT showed a nodular lesion of $37 \mathrm{~mm}$ that contacted the distal part of the aortic arch and $\mathrm{S} 1+2 \mathrm{seg}$ ment of the left lung.

(c): PET-CT showed the high-level accumulation of FDG (SUV-max: 6.05) in the nodule lesion. 

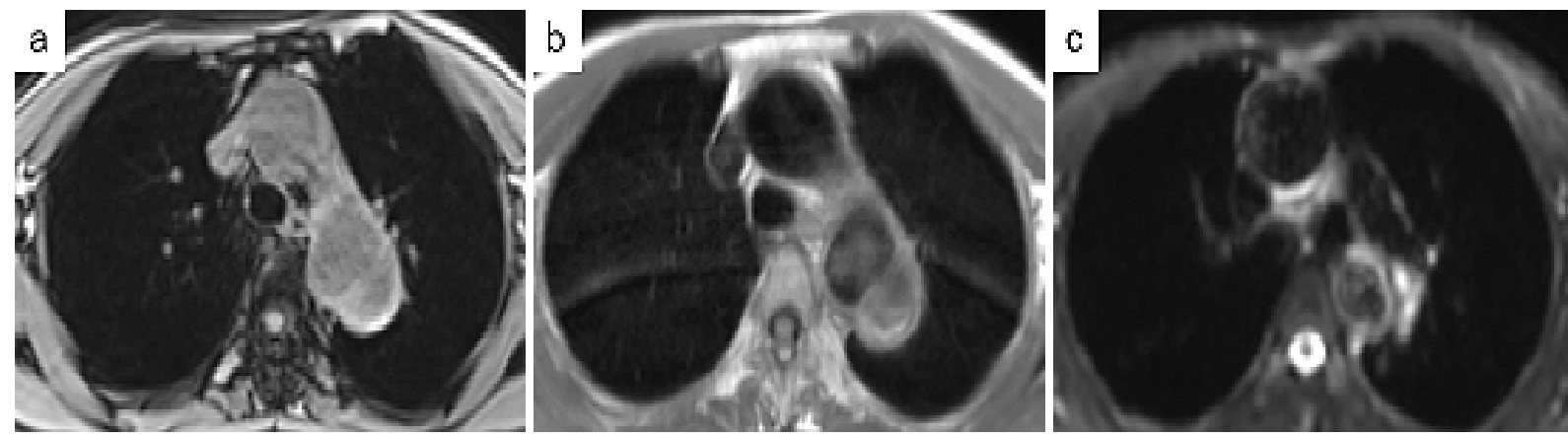

Fig. 3

(a): In T1-weighted images, the signal intensity of the tumor was the same as that of the aorta.

(b): In T2-weighted images, the inner dorsal part of the tumor showed a high signal, its bottom part showed a low signal, and its wall structure was thick.

(c): In diffusion-weighted images, higher signals were detected in the distal mass of the arch and outside of the wall, with a thickened aortic wall.

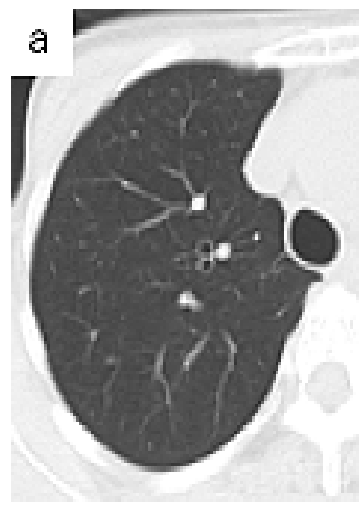

(a) (b): Chest CT showed a growi

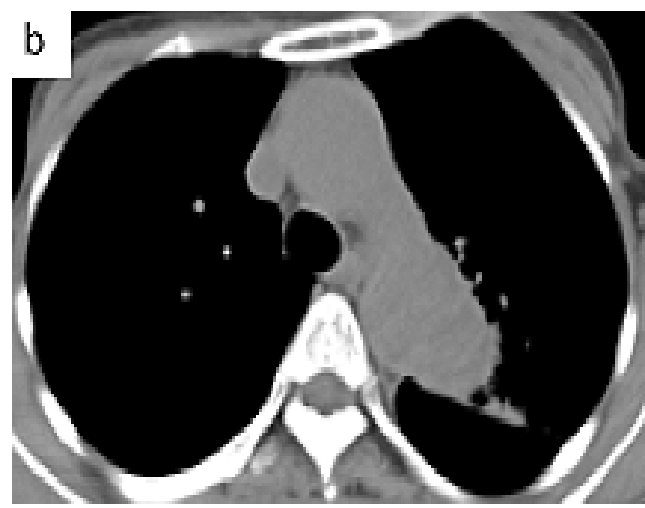

Fig. 4
見されるが, いずれも造影 CTによって mantle core sign を認めたことで診断に至ったと報告している ${ }^{4,5)}$. 本 症例においての反省点として造影 CT が最も有用であつ たことは確かではあるが, 大動脈解離等の鑑別の上で MRI angiography などを活用することも一つの方法で あったかもしれない.

稀ではあるが血管肉腫が胸部大動脈解離を起こした報 告例もある ${ }^{6)}$. この症例では造影 CT を施行し, 胸部大動 脈解離と診断した上で手術を施行している。しかし，術 後 3 力月の胸腹部造影 CT で全身に内部不均一の腫瘤を 認めたため, その後の検査で血管肉腫と診断された例も ある。我々が検索した範囲内で血管肉腫が大動脈解離を 引き起こした症例はこの 1 例のみではあったが，診断す る上で鑑別疾患として考慮する必要性があると考える.
また診断上, $\mathrm{MRI}^{7)}$ と $\mathrm{PET}-\mathrm{CT}^{8)}$, 経食道エコー ${ }^{9)}$ が腫瘍 性病変の鑑別に有用であったという報告例もある。本症 例でも MRI と PET-CT は施行されており, MRIにより, 胸部大動脈解離による大動脈炎と血管肉腫が鑑別疾患と された.また福田ら ${ }^{7)}$ は大動脈浸潤肺癌では $\mathrm{T} 1$ 強調画像 で大動脈周囲の脂肪層の消失, 腫瘍と連続して大動脈壁 が濃染されることから CTよりも MRIの方が有用性は あると報告している。 そのため大動脈近傍の腫瘤に関し ては積極的に MRIを施行した方が良いと考える.

また解離性大動脈瘤と肺癌の鑑別が困難であった文献 はいくつか散見される ${ }^{10,11)}$. CT にて解離性大動脈瘤を疑 い, 喀血や背部痛などの症状を呈している場合, 大動脈 解離による切迫破裂を考え, 緊急手術を選択せざるを得 なかったが結果的に肺癌であったとする報告もある ${ }^{12)}$. 

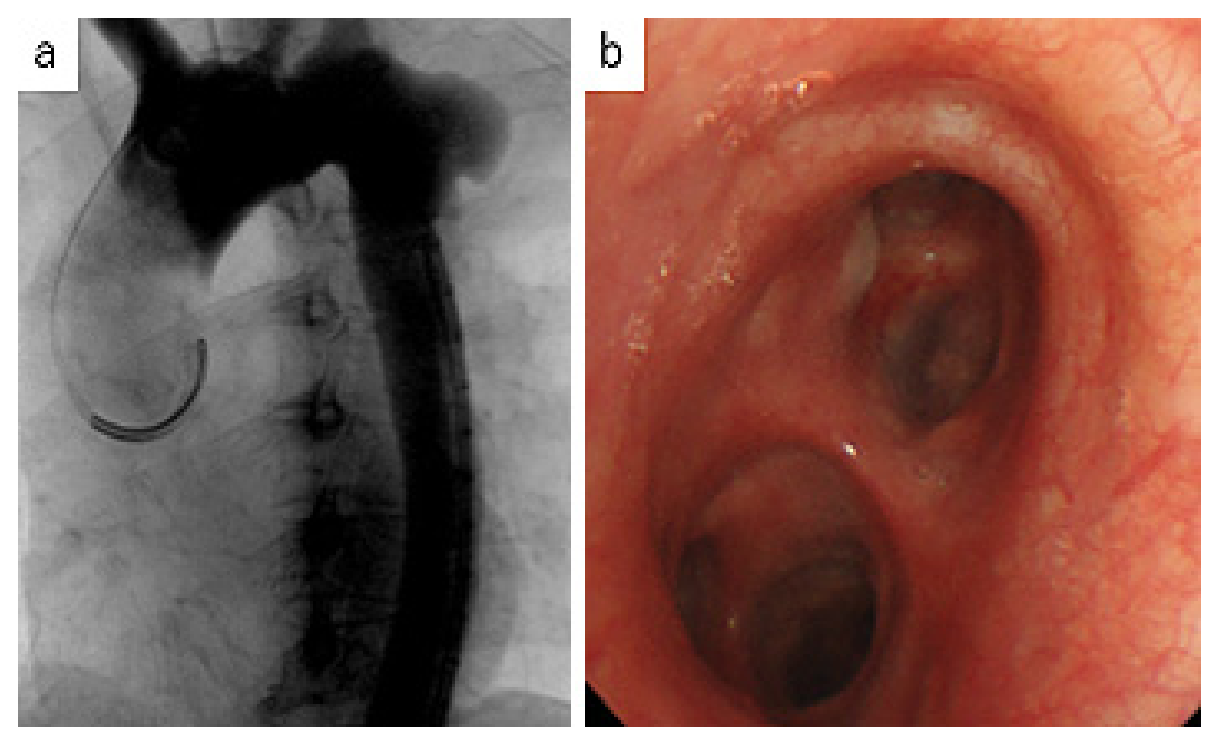

Fig. 5

(a): Emergent TEVAR was performed for thoracic aortic dissection.

(b): Bronchoscopic examination was performed, but washing cytology of the respiratory tract was negative.

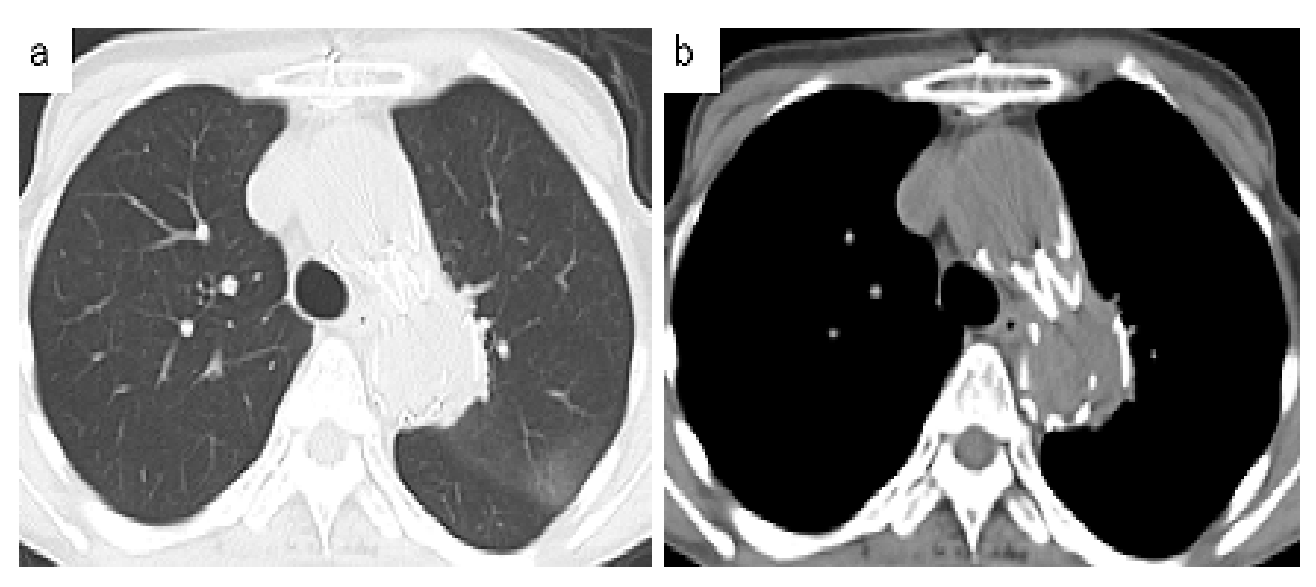

Fig. 6

(a) (b): Chest CT showed that the nodular lesion had decreased in size.

本症例は悪性腫瘍ではなかったが, 喀血を来たしたため, 緊急手術を施行している. そのため今後, 類似した症例, 特に緊急の症例であった場合には, 診断が非常に難しい と考えられた。また，胸腔鏡下肺生検術に関しても大動 脈瘤を合併した肺癌が考えられる場合には TEVAR 等 を施行後に出血のリスクを低くした上で施行し, 胸腔内 に明らかな腫瘍を認めた場合においてのみ生検をするこ とが重要であると考える.

本症例は肺癌と血管肉腫と大動脈解離による大動脈炎
の鑑別に難渋し, 結果的には大動脈解離による大動脈炎 ではあった，大動脈近傍に腫瘤を認めた場合には，緊急 手術を要さない場合には, 十分な検査を行い慎重な評価 と判断が必要であると考える.

\section{結論}

肺癌または血管肉腫との鑑別に難渋した 1 例を経験し た. 大動脈解離を伴った腫瘤を形成する大動脈炎では悪 性腫瘍の鑑別が困難であるため慎重な診断が要求され 
る.

\section{利益相反}

本論文について共著者の浦本 秀隆は 2019 年に日本 ベーリンガーインゲルハイム（株）より講演料を得てい る.

\section{文献}

1. Naruke T, Goya T, Tsuchiya R, Suemasu K. Prognosis and survival in resected lung carcinoma based on the new international staging system. J Thorac Cardiovasc Surg 1988; 96: 440-7.

2. Bode-Lesniewska B, Komminoth P. Intimal sarcoma. In: Fletcher CDM, Unni KK, Mertens F, editors. Pathology and Genetics of Tumours of Soft Tissue and Bone (WHO Classification of Tumours). Lyon: IARC Press; 2002: 2234.

3. 日本肺癌学会編. 肺癌診療ガイドライン 2018 年版. 第 5 版. 東京 : 金原出版；2018.

4. 仁科有美子, 土屋貴彦, 青木正紀, 山上賢治, 早川純子, 金子菜穂, 他. 胸部大動脈に病変を有する炎症性大動脈瘤 の一例．臨リウマチ 2009; 21: 169-73.

5. 犬塚和德, 海野直樹, 山本尚人, 相良大輔, 鈴木 実, 西 山元啓. ステントグラフト内㨂術が奏功した炎症性腹部 大動脈瘤の 1 例. 日血外会誌 $2007 ; \mathbf{1 6}: 679-83$.
6. 石井利治, 角野 聡, 平本明德, 斉藤隆之, 山中雄二. 術 後に多発性転移を生じた血管肉腫による遠位弓部大動脈 解離の 1 例. 日血外会誌 2007; 16: 625-8.

7. 福田 稔, 遠藤俊輔, 長谷川風, 山口 勉, 村山史雄, 蘇 原泰則，他. MRI 検查が有効であった大動脈浸潤肺癌の 一手術症例。日呼外会誌 1999; 13: 53-7.

8. Hsiao E, Laury A, Rybicki FJ, Menard MT, Ersoy H. Images in vascular medicine. Metastatic aortic intimal sarcoma: the use of PET/CT in diagnosing and staging. Vasc Med 2011; 16: 81-2.

9. Rhee MY, Myong NH, Park YB. Primary intimal sarcoma of the aorta: role of transesophageal echocardiography. Circ J 2002; 66: 111-3.

10. Sonker U, Peek DF, van der Meij JJ, Heijmen RH, Seldenrijk CA, Knaepen PJ. Primary lung tumor mimicking acute type A aortic dissection. Ann Thorac Surg 2004; 77: 1841-3.

11. Tsui P, Lee JH, MacLennan G, Capdeville M. Hemoptysis as an unusual presenting symptom of invasion of a descending thoracic aortic aneurysmal dissection by lung cancer. Tex Heart Inst J 2002; 29: 136-9.

12. 根本健司, 伊藤昌之, 仙波征太郎, 清水谷尚宏, 足立秀喜, 岸 厚次, 他. 胸部大動脈瘤破裂と鑑別が困難であった肺 癌の 1 例. 日呼吸会誌 2009; 47: 158-62. 


\title{
A case of thoracic aortic dissection that was difficult to differentiate from lung cancer or hemangiosarcoma
}

\author{
Shun Iwai, Aika Yamagata, Atsushi Sekimura \\ Nozomu Motono, Katsuo Usuda, Hidetaka Uramoto \\ Department of Thoracic Surgery, Kanazawa Medical University
}

The patient was a 50-year-old woman with a history of contrast medium allergy. A nodule shadow in the left lung was pointed out on a chest radiograph obtained in a health examination. Chest CT showed a nodular lesion of $37 \mathrm{~mm}$ that contacted the distal part of the aortic arch and S1+2 segment of the left lung. PET-CT showed the high-level accumulation of FDG (SUV-max: 6.05) in the nodule lesion, suggesting lung cancer or angiosarcoma. Chest MRI showed thoracic aortic dissection. After discussing treatment strategies with cardiovascular surgeons, we decided to perform stent-graft insertion (TEVAR) for thoracic aortic dissection and simultaneous thoracoscopic biopsy. However, hemoptysis occurred suddenly before the operation, the lesion expanded rapidly, and pulmonary hemorrhage was observed. Thus, emergent TEVAR was performed. Bronchoscopy was conducted postoperatively, but a definite diagnosis was not obtained. Fortunately, follow-up chest CT showed a decreased in the nodular lesion showed a decrease in the size, and the nodular lesion was judged as thoracic dissociative aortitis due to dissection of the thoracic aorta. The patient had a history of contrast medium allergy, and it is extremely difficult to make an accurate diagnosis of thoracic dissociative aortitis without the use of contrast medium on CT. It was fortunate for us not to perform trans-bronchoscopic biopsy, because the risk of bleeding would be high in thoracic dissociative aortitis. Thoracoscopic biopsy is the most useful method for distinguishing malignant tumors such as lung cancer from benign tumors. However, in the present patient, this was difficult to perform due to the coexistence of thoracic aortic dissection.

(C) The Japanese Association for Chest Surgery (JACS) 